\title{
Analysis of Pink Pigmented Facultative Methylotroph Bacteria from Human Environments
}

\author{
DIANA ELIZABETH WATURANGI* AND ANDREAS KUSUMA \\ School of Biotechnology, Universitas Katolik Indonesia Atma Jaya, \\ Jalan Jenderal Sudirman 51, Jakarta 12930, Indonesia
}

\begin{abstract}
The formation of pink biofilm in wet places are usually correlated with chlorine-resistant pink pigmented facultative methylotrophs (PPFM). In this study we investigated the presence of PPFM bacteria through bacterial isolation and detection of $m x a \mathrm{~F}$ gene from wet places of human-made environments. A total of eighteen PPFM bacterial isolates were recovered from the formation of biofilm bacterial of four test places such as washstands, bathrooms, and potable water supplies. Confirmation of the isolates through biochemical analysis were done using catalase, oxidase and urease tests. Chlorine-resistance-activity was assayed for all of the isolates. Antibiotic resistance were examined for ampicillin $(25 \mu \mathrm{g})$, tetracycline $(30 \mu \mathrm{g})$, $\mathrm{kanamycin}$ $(30 \mu \mathrm{g})$, trimethoprim $(1.25 \mu \mathrm{g})$, and streptomycin $(10 \mu \mathrm{g})$ using the agar diffusion method. Genomic DNA was subjected to PCR analysis with primers corresponding to the 5'- and 3'- end conserved segments of the mxaF gene. PCR amplification followed by DNA sequencing of $16 \mathrm{~S}$ rRNA gene were done for some isolates. We recovered 18 isolates of PPFM bacteria. Biochemical analysis indicated that the isolates were positive for catalase, oxidase, and urease activities. Chlorine-resistance-analysis showed the majority of the isolates were resistant to chlorine. Antibiotic resistance assays showed all of the isolates exhibited resistance to trimethoprim but were sensitive to streptomycin, kanamycin, and tetracycline but were variably resistant to ampicilin. PCR detection using specific primers for the $m x a \mathrm{~F}$ gene gave a positive result for all of the isolates. DNA sequencing of the 16S rRNA gene of two isolates showed that isolate WD10 had a 98\% similarity with the mxaF gene from Methylobacterium lusitanum strain MP2 and isolate WK2 had a 98\% similarity to the mxaF gene from Afipia felis strain RD1. The formation of pink biofilm of four wet areas in this study were correlated with the presence of chlorine-resistant PPFM bacteria and we confirmed with the presence of the $m x a \mathrm{~F}$ gene in all of the isolates. This finding needs to be widely publicized since some PPFM bacteria were known as opportunistic pathogens.
\end{abstract}

Key words: pink pigmented facultative methylotroph, human environments, chlorine resistance

Pink-pigmented facultative methylotrophs (PPFM) in the genus Methylobacterium is a physiologically interesting group of bacteria who preferentially utilize substrates lacking carbon-carbon bonds (e.g. methanol and methyl amine) as sources of energy and carbon, which is catalyzed by enzyme methanol dehydrogenase (Hanson and Hanson 1996). These organisms have been recognized as common environmental isolates from such habitats as leaf surfaces, soil-water, grasses and sewage (Hiraishi et al. 1995). These bacteria also occur in wet public environments, including potable water supplies, bathrooms and washstands, where they sometimes produce pink ropy masses of growth (Furuhata and Matsumoto 1992). Most of the Methylobacterium strains isolated from these environments are highly resistant to chlorine, moreover some PPFM bacteria are known as opportunistic pathogens (Hornei et al. 1999; Kelley et al. 2004). This study was designed to isolate, test for resistance to antibiotics, chlorine analysis and of the methanol dehydrogenase gene $(m x a \mathrm{~F})$ through PCR amplification.

\section{MATERIALS AND METHODS}

Bacterial Isolation and Identification. Biofilm formation of bacteria from human-made environments in Atma Jaya University were selected for bacterial isolation, including bathrooms, washstands and potable water supplies. Samples were streaked to minimal media agar supplemented with $1 \%$ methanol (v/v) and incubated at room temperature for

${ }^{*}$ Corresponding author, Phone: +62-21-5703306 ext. 335, Fax: +62-21-5719060, E-mail: diana.waturangi@atmajaya.ac.id
7 days. Identification was done through microscopic observation, morphological characteristics and biochemical analysis using oxidase and urease tests.

Antibiotic Resistance Analysis. Antibiotic resistance of the isolates was determined using the agar-disk-diffusiontest with disks containing ampicillin $(25 \mu \mathrm{g})$, tetracycline $(30 \mu \mathrm{g})$, kanamycin $(30 \mu \mathrm{g})$, trimethoprim $(1.25 \mu \mathrm{g})$ and streptomycin $(10 \mu \mathrm{g})$ (Oxoid, Hampshire, England). Colonies of the organisms were grown on standard agar $(0.25 \%$ yeast extract, $0.5 \%$ trypton, $0.1 \%$ D-glucose, $1.5 \%$ agar). Performance of the susceptibility testing and evaluation of the antibiograms after incubation for 5 days at $30^{\circ} \mathrm{C}$ followed the CLSI guidelines.

Chlorine Resistance Analysis. Colonies of the organism grown on Standard agar $(0.25 \%$ yeast extract, $0.5 \%$ trypton, $0.1 \% \mathrm{D}$-glucose, $1.5 \%$ agar) at $30^{\circ} \mathrm{C}$ for 5 days were harvested and chlorine resistance assays were done using the method published by Hiraishi et al. (1995).

PCR Amplification and DNA Sequencing of mxaF Gene. Genomic DNA was extracted and purified using the Wizard Genomic DNA Purification Kit (Promega, USA). The $m x a$ F genes were amplified from all of the DNA samples in 25- $\mu$ l reaction mixtures using PCR amplification (Perkin Elmer, USA). 2.5 U Taq polymerase (New England Biolabs, USA), $1 \mathrm{X}$ buffer, $1 \mu \mathrm{l}$ DNA template and 25 pmol forward primer f1003 (5'-GCGGCACCAACTGGGGCTGGT-3') and reverse primer r1561 (5'-GGGCAGCATGAGGGCTCCC-3') with 30 cycles of $92^{\circ} \mathrm{C}$ for $1 \mathrm{~min}, 55^{\circ} \mathrm{C}$ for $1 \mathrm{~min}$ and $72^{\circ} \mathrm{C}$ for $1 \mathrm{~min}$; followed by a final extension at $72^{\circ} \mathrm{C}$ for $5 \mathrm{~min}$. The PCR products were separated by agarose-gel-electrophoresis and purified using a QIAquick Gel Extraction Kit (Qiagen, 
Netherland). The $m x a \mathrm{~F}$ gene of two isolates were picked randomly and DNA sequencing continued using the BigDye Terminator v3.1 Cycle Sequencing Kit (Applied Biosystems, USA). The products were analyzed with an ABI prism 377 Automated DNA Sequencer. For comparison with known sequences, the Basic Local Alignment Search Tool (BLAST) computer search program was used.

\section{RESULTS}

Isolation and Identification of Bacteria. From the bacterial isolates we recovered 18 isolates of PPFM bacteria from 22 samples of human-made wet environments such as washstands, bathrooms and potable water supplies. All of the colonies showed pink colony, positive result for oxidase, catalase and urease activity and were identified as Gram negative bacteria through Gram staining.

Chlorine and Antibiotic Resistance Test. Chlorineresistance-analysis was performed on 9 isolates resistant to chlorine. Six of these isolates were recovered from washstands, 2 from bathrooms and 1 from a potable water supply. In the antibiotic resistance test, all of the isolates were resistant to trimethoprim and 5 isolates were resistant to ampicillin. All of the isolates were sensitive to the antibiotics streptomycin, kanamycin and tetracycline (Table 1).

Detection and DNA Sequencing of $m x a F$ Gene. Detection of the $m x a \mathrm{~F}$ gene using specific primers indicated that all of the isolates have positive results with the amplicon size $550 \mathrm{bp}$ (Fig 1). We took two isolates (WD10 and WK2) for DNA sequencing of the mxaF gene. Isolate WD10 showed 98\% similarity to Methylobacterium lusitanum strain MP2 and WK2 showed 98\% similarity to Methylobacterium sp. We have submitted this data to Genbank with the accession number EU563216 for isolate WD10 and accession number EU563217 for isolate WK2.

\section{DISCUSSION}

From this study, we have shown that PPFM bacteria are widely distributed in human-made wet environments, including washstands, bathrooms and potable water supplies. There are some published reports of the presence of these bacteria in wet environments such as drinking water, tap water, washstands, bathrooms and shower curtains and most of these are resistant to chlorine and antibiotics (Furuhata and Matsumoto 1992; Kelley et al. 2004). The presence of chlorine-resistant and antibiotic-resistant isolates in this study needs to be publicized (Table 1), since Methylobacterium species have also been attracting attention as opportunistic pathogens (Hornei et al. 1999). Antibiotic-resistance assays showed that all of the isolates were resistant to trimethoprim, sensitive to streptomycin, kanamycin and tetracycline, but variably resistant to ampicillin. Chen et al. (2004) reported that Methylobacterium isolated from urinary-tract-infected patients showed a high resistance to trimetophrim. Trimethoprim is often used for urinary infection treatments (Libecco and Powell 2004).

Most of the isolates showed resistance to chlorine with the highest percentage of isolates from the bathroom. This might be because of the frequent use of chlorine as a desinfectant in this environment. Hiraishi et al. (1995) reported that Methylobacterium strains acquire the capacity for chlorine resistance by adapting to chlorinated environments. Therefore, they can compete with coexisting chemoheterotrophs, and in some cases survive and exhibit massive growth in these environments (Chesney et al. 1996).

Fig 1 shows the presence of $m x a \mathrm{~F}$ gene in all of the isolates. Our data supports the literature about the ability of PPFM bacteria to utilize substrates lacking carbon-carbon bonds (Jeong et al. 2002). McDonald and Murrell (1997) reported the use of the methanol dehydrogenase structural gene $m x a F$ as a functional gene probe for methanotrophs and methylotrophs.

Washstands, bathrooms and potable water supplies are all oligotrophic environments, in which carbon energy sources for the growth of chemotrophic bacteria are very scant. The presence of $m x a \mathrm{~F}$ gene as one of the structural genes which encodes methanol dehydrogenase enzyme showed this capability. This enzyme carries out a key step in bacterial carbon-one ( $\mathrm{C} 1)$ metabolism since it catalyzes the

Table 1 Chlorine and antibiotics resistance test

\begin{tabular}{|c|c|c|c|c|c|c|c|}
\hline Name of isolate & Sample source & Amp & $\mathrm{Sp}$ & W & TE & $\mathrm{K}$ & Chlorine \\
\hline WD 1 & Washstand & I & $\mathrm{S}$ & $\mathrm{R}$ & $S$ & $\mathrm{~S}$ & $\mathrm{R}$ \\
\hline WD 2 & Washstand & $\mathrm{R}$ & $\mathrm{S}$ & $\mathrm{R}$ & $\mathrm{S}$ & $\mathrm{S}$ & $\mathrm{R}$ \\
\hline WD 3 & Washstand & I & S & $\mathrm{R}$ & S & $\mathrm{S}$ & $\mathrm{S}$ \\
\hline WD 4 & Washstand & I & $\mathrm{S}$ & $\mathrm{R}$ & $\mathrm{S}$ & $\mathrm{S}$ & $\mathrm{R}$ \\
\hline WD 5 & Washstand & $\mathrm{S}$ & $\mathrm{S}$ & $\mathrm{R}$ & $\mathrm{S}$ & $\mathrm{S}$ & $\mathrm{R}$ \\
\hline WD 6 & Washstand & $\mathrm{S}$ & $\mathrm{S}$ & $\mathrm{R}$ & $\mathrm{S}$ & $\mathrm{S}$ & $\mathrm{R}$ \\
\hline WD 7 & Washstand & I & $\mathrm{S}$ & $\mathrm{R}$ & $\mathrm{S}$ & $\mathrm{S}$ & $\mathrm{R}$ \\
\hline WD 8 & Washstand & $\mathrm{R}$ & $\mathrm{S}$ & $\mathrm{R}$ & $\mathrm{S}$ & $\mathrm{S}$ & $\mathrm{S}$ \\
\hline WD 9 & Washstand & $\mathrm{R}$ & $\mathrm{S}$ & $\mathrm{R}$ & $\mathrm{S}$ & $\mathrm{S}$ & $\mathrm{S}$ \\
\hline WD 10 & Washstand & I & $\mathrm{S}$ & $\mathrm{R}$ & $\mathrm{S}$ & $\mathrm{S}$ & $\mathrm{S}$ \\
\hline WK 1 & Washstand & I & $\mathrm{S}$ & $\mathrm{R}$ & $\mathrm{S}$ & $\mathrm{S}$ & $\mathrm{S}$ \\
\hline WK 2 & Washstand & I & $\mathrm{S}$ & $\mathrm{R}$ & $\mathrm{S}$ & $\mathrm{S}$ & $\mathrm{S}$ \\
\hline WK 3 & Washstand & I & $\mathrm{S}$ & $\mathrm{R}$ & $\mathrm{S}$ & $\mathrm{S}$ & $\mathrm{S}$ \\
\hline WK 4 & Washstand & $\mathrm{R}$ & $\mathrm{S}$ & $\mathrm{R}$ & $\mathrm{S}$ & $\mathrm{S}$ & $\mathrm{S}$ \\
\hline KM 1 & Bathroom & $\mathrm{R}$ & $\mathrm{S}$ & $\mathrm{R}$ & $\mathrm{S}$ & $\mathrm{S}$ & $\mathrm{R}$ \\
\hline KM 2 & Bathroom & $\mathrm{S}$ & $\mathrm{S}$ & $\mathrm{R}$ & $\mathrm{S}$ & $\mathrm{S}$ & $\mathrm{R}$ \\
\hline TA 1 & Potable water supply & $\mathrm{S}$ & $\mathrm{S}$ & $\mathrm{R}$ & $\mathrm{S}$ & $\mathrm{S}$ & $\mathrm{R}$ \\
\hline TA 2 & Potable water supply & $\mathrm{S}$ & $\mathrm{S}$ & $\mathrm{R}$ & $\mathrm{S}$ & $S$ & $\mathrm{~S}$ \\
\hline
\end{tabular}

R: resistant, I: intermediate, S: susceptible, Amp: ampicillin, S: streptomycin, W: trimethoprim, TE: tetracycline, K: kanamycin. 


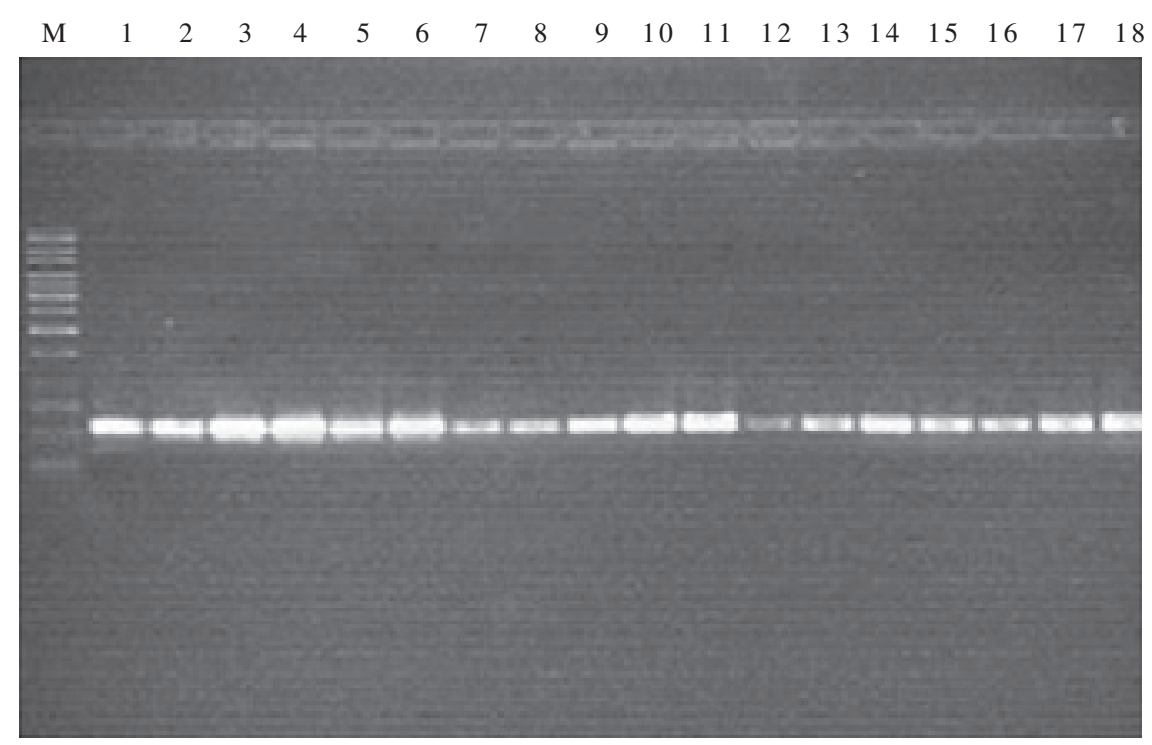

Fig 1 Detection of mxaF genes of PPFM isolates: M 1 kb DNA Ladder; well 1-10, isolates (WD1-WD10); well 11-14, isolates (WK1WK4); well 15-16, isolates from potable water supply (TA1-TA2); well 17-18, isolates from bathrooms (KM1-KM2).

production of formaldehyde, the intermediate of both assimilative and dissimilative metabolism in methylotrophs.

DNA sequencing of the 16SrRNA gene of the two isolates showed that isolate WD10 had a $98 \%$ similarity with the $m x a$ F gene from $M$. lusitanum strain MP2. This was submitted to the Genbank with accession number EU563216. Isolate WK2 had a $98 \%$ similarity to the mxaF gene from A. felis strain RD1, with the accession number EU563217. The formation of pink biofilm in four wet places in this study were correlated with the presence of chlorine-resistant PPFM bacteria. This was confirmed with the presence of the $m x a \mathrm{~F}$ gene in all of the isolates. This finding need to be widely distributed since some PPFM bacteria were known to be opportunistic pathogens.

\section{ACKNOWLEDGEMENT}

This work was supported by Atma Jaya Research Center, Atma Jaya Catholic University of Indonesia.

\section{REFERENCES}

Chen HL, Ya FT, Jien WL. 2004. Underdiagnosis of urinary tract

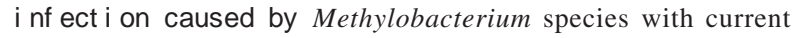
standard processing of urine culture and its clinical implications. J Med Microbiol 53:755-759.
Chesney JA, Eaton JW, Mahoney JR. 1996. Bacterial glutathione: a sacrificial defense against chlorine compounds. J Bacteriol 178:2131-2135.

Furuhata K, Matsumoto A. 1992. Some bacteriological studies on the pinkish slimy films formed on tiles using bathrooms and washstands. Annu Rep Tokyo Metrop Res Lab Public Health 43:197-204.

Hanson RS, Hanson TE. 1996. Methanotrophic bacteria. Microbiol Rev 60:439-471.

Hiraishi A, Furuhata K, Matsumoto A, Koike KA, Fukuyama M, Tabuchi K. 1995. Phenotypic and genetic diversity of chlorineresistant Methylobacterium strains isolated from various environments. Appl Environ Microbiol 61:2099-2107.

Hornei B, Luneberg E, Schmidt-Rotte H, Maass M, WeberK, Heits F, Frosch M, Solbach W. 1999. Systemic infection of an immunocompromised patient with Methylobacterium zatmanii. J Clin Microbiol 37:248-250.

Jeong JH, Kim SW, Yoon SM, Park JK, Lee JS. 2002. Characterization of the conserved region of the mxaF gene that encodes the large subunit of methanol dehydrogenase from a marine methylotrophic bacterium. Mol Cells 13:369-376.

Kelley ST, Theisen U, Angenent LT, Amand AS, Pace NR. 2004. Molecular analysis of shower curtain biofilm microbes. Appl Environ Microbiol 70:4187-4192.

Libecco JA, Powell KR. 2004. Trimethoprim/sulfamethoxazole: clinical update. Pediatrics Rev 25:375-379.

McDonald IR, Murrell JC. 1997. The methanol dehydrogenase structural gene mxaF and its use as a functional gene probe for methanotrophs and methylo-trophs. Appl Environ Microbiol 63:3218-3224. 